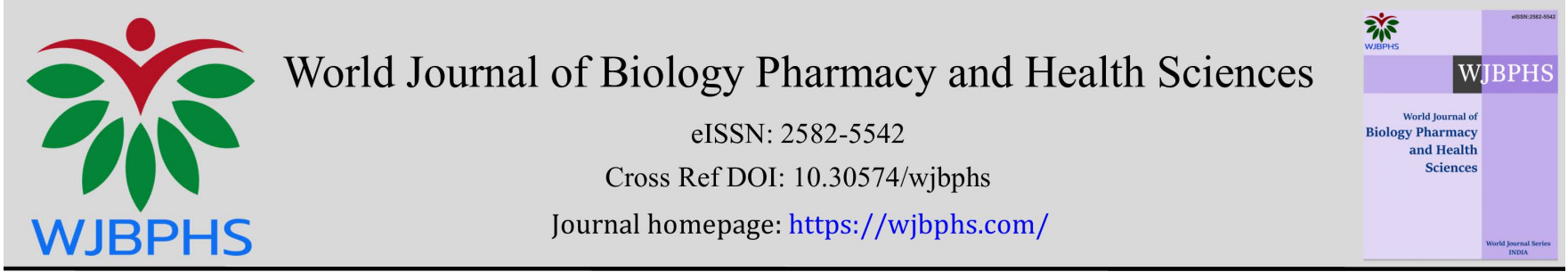

(RESEARCH ARTiCLE)

\title{
Chemical composition and antimicrobial activity of essential oil of Verbena rigida Spreng.
}

Taghreed Abdou Ibrahim 1, 2, *

${ }^{1}$ Department of Pharmacognosy, College of Pharmacy, King Saud University, Riyadh 11549.

2 Department of Pharmacognosy, Faculty of Pharmacy, Cairo University, Cairo, Egypt.

World Journal of Biology Pharmacy and Health Sciences, 2022, 09(01), 039-045

Publication history: Received on 14 December 2021; revised on 19 January 2022; accepted on 21 January 2022

Article DOI: https://doi.org/10.30574/wjbphs.2022.9.1.0026

\begin{abstract}
The study was planned to determine the chemical composition and antimicrobial properties of the essential oil of Verbena rigida Spreng. cultivated in Egypt. The essential oil from aerial parts of Verbena rigida Spreng. was prepared by hydrodistillation in a yield of $0.26 \% \mathrm{v} / \mathrm{w}$. The chemical composition of the essential oil has been elucidated by gas chromatography-mass spectroscopy analysis. The prepared essential oil was tested against selected species of Grampositive, Gram-negative bacteria and Candida species using disc diffusion method and MICs were determined using broth micro-dilution method. Twenty-eight compounds were identified in the essential oil of Verbena rigida, the major components were isobornyl formate (35.2\%) and citral (32.9\%). The essential oil showed significant antimicrobial activities against Staphylococcus aureus, Staphylococcus epidermidis, Bacillis subtilis, Escherichia coli and Pseudomonas aeruginosa with MIC $25 \mu \mathrm{g} / \mathrm{mL}$ for E. coli and $50 \mu \mathrm{g} / \mathrm{mL}$ for other sensitive bacteria. This is the first study of the chemical composition and antimicrobial activity of the essential oil of $V$. rigida, it proved that the essential oil of $V$. rigida possesses potential antimicrobial properties and could in the future represent a new source of natural antiseptic agents.
\end{abstract}

Keywords: Verbena rigida; Isobornyl formate; Citral; Antimicrobial; Essential oil

\section{Introduction}

Despite remarkable progress made in medicine, transmissible diseases caused by bacteria, fungi, viruses, and parasites remain major health threats globally. Their impacts are chiefly massive in developing countries where there is extensive unavailability of modern medicines and a high rate of development of drug resistance [1]. The emergence of drug resistance, as well as lack of availability of certain antibiotics, must lead to the search of new antimicrobial agents mainly from natural sources with the goal to discover new chemical agents, which overcome these problems [2]. Current research on naturally occurring compounds and products chiefly focus on plants since they are locally available, less costly, and can be chosen based on existing ethnomedicinal claims for their uses [3].

Several Verbena species (Verbenaceae) are traditionally used in many countries to treat diarrhea, fever, gastrointestinal disorders and some sexually transmitted diseases [4]. In addition to antidepressant, ant-jaundice, diuretic, expectorant and anti-influenza effects [5]. Monographs on "Verbenae herba" have been included in the European Pharmacopoeia since 2008, and in the Chinese Pharmacopoeia since 1995 [6].

Numerous Verbena species were previously investigated and found to have different flavonoids [4, 7-12], in addition to phenolic acids [13], iridoids [14-19], phenylethanoids [17], phenylpropanoids [18,19] and essential oils [20-24].

\footnotetext{
* Corresponding author: Taghreed Abdou Ibrahim

Department of Pharmacognosy, College of Pharmacy, King Saud University, Riyadh 11549.

Copyright (@ 2022 Author(s) retain the copyright of this article. This article is published under the terms of the Creative Commons Attribution Liscense 4.0.
} 
Essential oils of several Verbena species were investigated, their chemical composition have been studied [5,20-24] and proved to have anticancer [24] and antimicrobial activities [20,21].

Verbena rigida, known as slender vervain or tuberous vervain, is a flowering herbaceous perennial plant in the family Verbenaceae [25]. It is native to Brazil and Argentina, and grown in temperate climates, as an ornamental plant [26].

The scientific literature on Verbena rigida studied its flavonoid content [12] but nothing was found about its essential oil composition and biological activity. The present study was established to evaluate the antimicrobial activity of the essential oil of Verbena rigida aerial parts and determine its chemical composition in order to correlate between its chemical composition and potential antimicrobial activity.

\section{Material and methods}

\subsection{Plant material}

Aerial parts of Verbena rigida Spreng. was collected from the Garden of Faculty of Agriculture, Al-Azhar University, Cairo, Egypt at its flowering stage (April 2020). The plants were kindly, previously, identified by Dr. Adel Okeal, Director of El-Orman Gardens, Giza, Egypt. A voucher herbarium specimen had been deposited in the Department of Pharmacognosy, Faculty of Pharmacy, Cairo University, Cairo, Egypt.

\subsection{Preparation of the essential oil}

The essential oil was prepared from the fresh aerial parts of Verbena rigida ( $500 \mathrm{~g}$ ) by hydro distillation using Clevengertype apparatus. The oil was dried over anhydrous sodium sulphate and stored in sealed glass vials at 4-6 ${ }^{\circ} \mathrm{C}$ prior to analysis. Percentage yield was determined according to European Pharmacopoeia 2004 [27]

\subsection{GC/MS analysis of the essential oil}

The prepared essential oil was subjected to GC/MS analysis using Shimadzu GC//MS - QP 5050 A, fitted with an HP-5 MS capillary column (30 m x 0.25 mm i.d.; $0.25 \mu \mathrm{m}$ film thickness). Software Class 5000 searched library: Wiley 229 LIB. Carrier gas: Helium (flow rate $1 \mathrm{~mL} / \mathrm{min}$ ). Ionization mode: EL (70 ev). Temperature program: $40{ }^{\circ} \mathrm{C}$ (static for $2 \mathrm{~min}$ ) then gradually increasing at a rate of $2{ }^{\circ} \mathrm{C} / \mathrm{min}$ up to $250{ }^{\circ} \mathrm{C}$ (static for $8 \mathrm{~min}$ ). Detector temperature $250{ }^{\circ} \mathrm{C}$. Injector temperature $250^{\circ} \mathrm{C}$.

\subsection{Identification of the essential oil}

Compounds were identified by comparison of their retention indices (RI), obtained on HP-5 MS colum relative to C5C24 n-alkanes, with those provided in the literature, in addition to Library searched data base Willey 229 LIB and by comparing mass fragmentation patterns with those of the available references and with published data [5,22-24, 2834].

The percentage composition of the essential oil was determined by computerized peak area measurements. Results were calculated as mean values after three injections of the essential oil and presented in Table 1.

\subsection{Test organisms}

Pure bacterial strains collected according to American Type Culture Collection (ATCC) were used, Gram +ve: Staphylococcus aureus ATCC 13709, Staphylococcus epidermidis ATCC 35984, Streptococcus pyogenes ATCC 19615 and Bacillus subtilis ATCC 6051, Gram -ve: Escherichia coli ATCC 9637, Klebsiella pneumoniae ATCC 1705, Proteus vulgaris ATCC 8427, Pseudomonas aeruginosa ATCC 27853 and Shigella boydii ATCC 9905) as well as pure strains of Candida albicans ATCC 10231, C. glabrata ATCC 90030, C. krusei ATCC 14243 and C. parapsilosis ATCC 22019. All microorganisms were kindly supplied from the Regional Center for Mycology and Biotechnology (RCMB), Al-Azhar University, Cairo, Egypt.

\subsection{Testing for antimicrobial activities}

Screening of the antimicrobial activity of the essential oil was adopted according to CLSI standards [35], using disc-agar diffusion method [36]. Sterile nutrient agar (Immun präparate, Berlin, D, 26 g agar/L. distilled water) was inoculated with bacterial cells $(100 \mu \mathrm{l}$ of bacterial cell suspension in $25 \mathrm{~mL}$ medium) and poured into dishes to give a solid plate. Determination of antimicrobial activities against Candida species was achieved by agar-disc diffusion method using 
sterile Mueller-Hinton agar (Becton Dickinson, Heidelberg). Ten microlitres of essential oil, dissolved in dimethylsulfoxide (DMSO, Merck, Germany), was applied to sterile paper discs (6 mm diameter) which were placed on the agar surface cultivated with the selected microorganisms. Petri dishes were incubated at $37^{\circ} \mathrm{C}$ for $24 \mathrm{~h}$ in case of bacteria and for $48 \mathrm{~h}$ at $30^{\circ} \mathrm{C}$ in case of Candida. Gentamycin (Sigma Aldrich, Steinheim, Germany) and nystatin (Merck, Darmstadt, Germany) in concentration range $(0.001-64.00 \mu \mathrm{g} / \mathrm{mL}$, sterile distilled water) were used as standard antibacterial and antifungal drugs, respectively. DMSO without the essential oil was used as the negative control.

Minimum Inhibitory Concentrations (MICs) were determined using the broth microdilution method [35,36]. Test yeasts or bacteria strains were suspended in media and the cell densities were adjusted to $0.5 \mathrm{McFarland}$ standards at $530 \mathrm{~nm}$ wavelength using a spectrophotometeric method. Inoculums $(0.1 \mathrm{~mL})$ were added to the microtiter plates, which were incubated in a humid atmosphere at $30{ }^{\circ} \mathrm{C}$ for $24-48 \mathrm{~h}$ (yeast) or at $37{ }^{\circ} \mathrm{C}$ for $24 \mathrm{~h}$ (bacteria). In addition, positive (medium with inoculums but with no essential oil) and negative (Uninoculated medium, $200 \mu \mathrm{L}$ ) growth controls were prepared. The growth in each well was compared with the growth in the control wells. MICs were visually determined and defined as the lowest concentration of the essential oil produced $\geq 50 \%$ growth inhibition for yeast and $\geq 95 \%$ growth reduction for bacteria compared with the growth in the control well. Each experiment was performed in triplicate, results were calculated as mean values and presented in Table 2.

\subsection{Statistical analysis}

Results were expressed as the mean \pm standard deviation; statistical analysis of experimental results were based on the analysis of variance method. Differences were considered statistically significant at the level of $\mathrm{P}<0.05$.

\section{Results}

\subsection{GC-MS analysis of essential oil}

The yield of essential oil prepared by hydro-distillation from the aerial parts of $V$. rigida was $0.26 \% \mathrm{v} / \mathrm{w}$. The results of GC-MS analysis of the essential oil are presented in table 1, which reports the percentage composition of the essential oil, twenty-eight compounds were detected and identified. The oil is mainly constituted by monoterpenes (91.2\%), oxygenated monoterpene compounds constitute 83.7\%; isobornyl formate is the main constituent (35.2\%) followed by citral $(32.9 \%)$. Sesquiterpenes constitute $8.8 \%$ of oil composition of which $6 \%$ are hydrocarbons, predominated by spathulenol (2.5\%). This is the first study of the chemical composition of essential oil of $V$. rigida, it differs from reported in literature for other Verbena species.

Table 1 Chemical composition of the essential oil of $V$. rigida

\begin{tabular}{|c|c|l|c|c|}
\hline No. & KI$^{*}$ & \multicolumn{1}{|c|}{ Compound } & Formula & Percentage (Mean \pm SD) ${ }^{* *}$ \\
\hline 1 & 936 & $\alpha$-Pinene & $\mathrm{C}_{10} \mathrm{H}_{16}$ & $0.5 \pm 0.0$ \\
\hline 2 & 973 & Sabinene & $\mathrm{C}_{10} \mathrm{H}_{16}$ & $1.2 \pm 0.0$ \\
\hline 3 & 978 & $\beta$-Pinene & $\mathrm{C}_{10} \mathrm{H}_{16}$ & $1.4 \pm 0.0$ \\
\hline 4 & 1016 & $\alpha$-Terpinene & $\mathrm{C}_{10} \mathrm{H}_{16}$ & $0.9 \pm 0.0$ \\
\hline 5 & 1041 & $o$-Cymene & $\mathrm{C}_{10} \mathrm{H}_{14}$ & $0.4 \pm 0.0$ \\
\hline 6 & 1029 & Limonene & $\mathrm{C}_{10} \mathrm{H}_{16}$ & $1.7 \pm 0.0$ \\
\hline 7 & 1030 & $\beta$-Phellandrene & $\mathrm{C}_{10} \mathrm{H}_{16}$ & $1.2 \pm 0.0$ \\
\hline 8 & 1033 & 1,8 -Cineole & $\mathrm{C}_{10} \mathrm{H}_{18} \mathrm{O}$ & $4.8 \pm 0.0$ \\
\hline 9 & 1086 & Terpinolene & $\mathrm{C}_{10} \mathrm{H}_{16}$ & $0.2 \pm 0.0$ \\
\hline 10 & 1098 & Linalool & $\mathrm{C}_{10} \mathrm{H}_{18} \mathrm{O}$ & $4.5 \pm 0.1$ \\
\hline 11 & 1152 & Iso-pinocarvone & $\mathrm{C}_{10} \mathrm{H}_{14} \mathrm{O}$ & $0.1 \pm 0.0$ \\
\hline 12 & 1163 & Pinocarvone & $\mathrm{C}_{10} \mathrm{H}_{14} \mathrm{O}$ & $0.3 \pm 0.0$ \\
\hline 13 & 1167 & Borneol & $\mathrm{C}_{10} \mathrm{H}_{18} \mathrm{O}$ & $3.7 \pm 0.0$ \\
\hline 14 & 1189 & $\alpha$-Terpineol & $\mathrm{C}_{10} \mathrm{H}_{18} \mathrm{O}$ & $0.5 \pm 0.0$ \\
\hline
\end{tabular}




\begin{tabular}{|c|c|l|c|c|}
\hline 15 & 1228 & Isobornyl formate & $\mathrm{C}_{11} \mathrm{H}_{18} \mathrm{O}_{2}$ & $35.2 \pm 0.1$ \\
\hline 16 & 1270 & Citral & $\mathrm{C}_{10} \mathrm{H}_{16} \mathrm{O}$ & $32.9 \pm 0.0$ \\
\hline 17 & 1284 & Bornyl acetate & $\mathrm{C}_{12} \mathrm{H}_{20} \mathrm{O}_{2}$ & $0.3 \pm 0.0$ \\
\hline 18 & 1286 & Isobornyl acetate & $\mathrm{C}_{12} \mathrm{H}_{20} \mathrm{O}_{2}$ & $1.4 \pm 0.0$ \\
\hline 19 & 1377 & $\alpha$-Copaene & $\mathrm{C}_{15} \mathrm{H}_{24}$ & $0.6 \pm 0.0$ \\
\hline 20 & 1390 & $\beta$-Elemene & $\mathrm{C}_{15} \mathrm{H}_{24}$ & $0.2 \pm 0.0$ \\
\hline 21 & 1407 & Longifolene & $\mathrm{C}_{15} \mathrm{H}_{24}$ & $1.4 \pm 0.0$ \\
\hline 22 & 1418 & $\beta$-Caryophyllene & $\mathrm{C}_{15} \mathrm{H}_{24}$ & $0.9 \pm 0.0$ \\
\hline 23 & 1424 & $\beta$-Cedrene & $\mathrm{C}_{15} \mathrm{H}_{24}$ & $1.3 \pm 0.0$ \\
\hline 24 & 1461 & Alloaromadendrene & $\mathrm{C}_{15} \mathrm{H}_{24}$ & $1.2 \pm 0.0$ \\
\hline 25 & 1494 & Bicyclogermacrene & $\mathrm{C}_{15} \mathrm{H}_{24}$ & $0.4 \pm 0.0$ \\
\hline 26 & 1576 & Spathulenol & $\mathrm{C}_{15} \mathrm{H}_{24} \mathrm{O}$ & $2.5 \pm 0.0$ \\
\hline 27 & 1581 & Caryophyllene oxide & $\mathrm{C}_{15} \mathrm{H}_{24} \mathrm{O}$ & $0.2 \pm 0.0$ \\
\hline 28 & 1633 & Iso-spathulenol & $\mathrm{C}_{15} \mathrm{H}_{24} \mathrm{O}$ & $0.1 \pm 0.0$ \\
\hline
\end{tabular}

In fact, verbenone [22], 1-octen-3-ol [20,22], 2-pentadecanone 6, 10, 14-trimethyl and phytol [20], which were previously detected in the essential oil of $V$. officinalis collected from Iran and $V$. bonariensis, are totally absent in $V$. rigida essential oil under investigation. On the other hand, spathulenol, limonene and 1,8-cineole which were detected in essential oil of $V$. rigida under investigation, have been reported as principal constituents of essential oil of $V$. officinalis from Morocco [23]. Trans-isoelemicin and dihexyl phthalate were undetected in the essential oil of $V$. rigida while trans-isoelemicin was the major component of the volatile constituents in $V$. venosa and dihexyl phthalate was the major component of the volatile constituents in $V$. bonariensis, $V$. hybrida and $V$. supine [5]. Citral and isobornyl formate which are the major constituents in the essential oil of $V$. rigida under investigation, have been previously detected as major constituents of $V$. officinalis from Italy [24].

\subsection{Evaluation of antimicrobial activity}

Table 2 Antimicrobial activity and MIC of essential oil of $V$. rigida

\begin{tabular}{|c|c|c|c|c|}
\hline Microorganism & $\begin{array}{r}D \\
(M\end{array}$ & $\begin{array}{l}\mathrm{D}^{\mathrm{a}} \\
\mathrm{SD})\end{array}$ & & $\begin{array}{l}C^{\mathbf{b}} \\
\mathrm{mL})\end{array}$ \\
\hline & Tonotiol & Standard & Tonotial & Standard \\
\hline Gram +ve Bacteria & Essentiat oi & Gentamycin & ESSETIIAT UI & Gentamycin \\
\hline Staphylococcus aureus & $19.4 \pm 0.4^{*}$ & $24.6 \pm 0.5$ & 50 & $8 \times 10^{-3}$ \\
\hline Staphylococcus epidermidis & $18.7 \pm 0.3^{*}$ & $25.3 \pm 0.4$ & 50 & $1 \times 10^{-2}$ \\
\hline Streptococcus pyogens & $12.3 \pm 0.2$ & $24.5 \pm 0.3$ & NT & NT \\
\hline Bacillus subtilis & $17.5 \pm 0.5^{*}$ & $26.4 \pm 0.4$ & 50 & $1 \times 10^{-2}$ \\
\hline Gram -ve Bacteria & & Gentamycin & & Gentamycin \\
\hline Escherichia coli & $23.6 \pm 0.4^{*}$ & $26.7 \pm 0.9$ & 25 & $8 \times 10^{-3}$ \\
\hline Klebsiella pneumonia & $11.8 \pm 0.2$ & $23.7 \pm 0.6$ & NT & NT \\
\hline Proteus vulgaris & $12.4 \pm 0.1$ & $25.5 \pm 0.5$ & NT & NT \\
\hline Pseudomonas aeruginosa & $19.4 \pm 0.2^{*}$ & $22.4 \pm 0.3$ & 50 & $1 \times 10^{-2}$ \\
\hline Shigella boydii & $12.7 \pm 0.2$ & $21.8 \pm 0.4$ & NT & NT \\
\hline
\end{tabular}




\begin{tabular}{|c|c|c|c|c|}
\hline \multicolumn{2}{|l|}{ Fungi } & \multirow{2}{*}{$\begin{array}{l}\text { Nystatin } \\
15.4 \pm 0.1\end{array}$} & \multirow[b]{2}{*}{ NT } & \multirow{2}{*}{$\begin{array}{r}\text { Nystatin } \\
\text { NT }\end{array}$} \\
\hline Candida albicans & $8.6 \pm 0.2$ & & & \\
\hline Candida glabrata & $9.2 \pm 0.2$ & $16.7 \pm 0.4$ & NT & NT \\
\hline Candida krusei & $10.2 \pm 0.1$ & $15.6 \pm 0.3$ & NT & NT \\
\hline Candida parapsilosis & $8.7 \pm 0.2$ & $15.8 \pm 0.1$ & NT & NT \\
\hline
\end{tabular}

Results of evaluation of the antimicrobial activity, obtained from agar disc diffusion method and measurement of MICs, revealed that the essential oil of $V$. rigida exhibits a significant antibacterial activity (Table 2) against Gram +ve bacteria with a remarkable effect on the growth of Staphylococcus aureus, Staphylococcus epidermidis and Bacillus subtilis, with MIC of $50 \mu \mathrm{g} / \mathrm{mL}$. The essential oil also showed a significant growth inhibitory effect against the Gram -ve bacteria, $E$. coli and Pseudomonas aeruginosa (MIC, 25 and $50 \mu \mathrm{g} / \mathrm{mL}$, respectively) and no significant antifungal activity against tested species were detected.

\section{Discussion}

Twenty-six of the detected compounds in the essential oil of $V$. rigida were previously detected in essential oil of $V$. officinalis growing in Italy with different concentrations [24]. The composition of the essential oil is greatly different than the previously reported in V. officinalis growing either in Iran or Morcco [22,23], and differs than the composition of essential oil of $V$. bonariensis which contains 21 components, from which only terpineol is detected in $V$. rigida [20]. Also, the composition of the essential oil of $V$. rigida have been proved to be totally different than several other Verbena species collected from Egypt [5]. The difference in composition is most likely attributed to climate, soil composition, altitude and age as well as species variation [37].

The antimicrobial activity of the major compounds of the investigated oil has been previously well defined by several researchers. The oil components, namely limonene [38], linalool [38,39], borneol [38,40], $\alpha$-terpineol [38], citral [38,21], 1,8-cineole [41] $\alpha$-pinene and $\beta$-pinene [42] have been reported to display antibacterial activity against several bacterial species.

The presence of these compounds in the essential oil of V. rigida may account for its observed antimicrobial activity.

The results of this study on the chemical composition and antimicrobial activity of $V$. rigida essential oil are the first to be reported. These findings support the observations of some other researchers which proved that essential oil of $V$. bonariensis showed inhibitory activity against Pseudomona aeruginosa (50\%) and Klebsiella pneumoniae (22\%) growth but with no activity against Escherichia coli [20].

\section{Conclusion}

In this study, the chemical composition and the antimicrobial activity of the essential oil of aerial parts of $V$. rigida were investigated for the first time. The oil is rich in oxygenated monoterpene constituents especially isobornyl formate and citral and showed significant in vitro antibacterial activity against tested microorganisms. Further in vivo studies are needed to ensure the antibacterial activity and possible use of the essential oil of $V$. rigida as an antimicrobial agent.

\section{Compliance with ethical standards}

\section{Disclosure of conflict of interest}

The author declares no conflict of interest.

\section{References}

[1] Alberto R, Zampini C, Cuello S, Ordonez M, Almeida D, Solorzano E, Isla I. Antimicrobial activity of selected plant species from the Argentine puna against sensitive and multi-resistant bacteria. J Ethnopharmacol. 2009; 124: 499-505. 
[2] Benharref A, Bouamama H, Noel T, Villard J, Jana M. Antimicrobial activities of the leaf extract of two Moroccan Cistus Linn. species. J Ethnopharmacol. 2006; 104: 104-7.

[3] Arora S, Kaur J. Antibacterial activity of some Indian medicinal plants. J Nat Med. 2007; 61: 313-17.

[4] El-Hela AA, Alkhadrawy FM, Abdel-Hady NM. Flavone C-glycosides from Verbena bonariensis L. cultivated in Egypt. Al-Azhar Journal of Natural Products. 2007; 31: 41.

[5] Al-Amier H, El-Hela AA, Al-Khadrawy FM, Craker LE. Comparative evaluation of the volatile constituents in some Verbena species cultivated in Egypt. J Herbs Spices Med Plants. 2005; 11(3): 25-33.

[6] Kubica P, Szopa A, Dominiak J, Luczkiewicz M, Ekiert H. Verbena officinalis (Common Vervain) - A review on the investigations of this medicinally important plant species. Planta Med. 2020; 86(17): 1241-57.

[7] El-Hela AA, Singab AB, El Azizi MM. Flavon C - glucosides from Verbena bipinnatifida (Nutt). Azhar J. Pharm. Sci. 2000; 25: 232- 7 .

[8] El-Hela AA, Ismail SK. Quantitative estimation of flavone C-glycosides in some plants belonging to Verbenaceae family. Azhar J. Pharm. Sci. 2002; 28: 152- 62.

[9] Kawashty SA, El-Garf IA. The flavonoid chemosystematics of Egyptian Verbena species. Biochem. Syst. Ecol. 2000; 28: $919-21$.

[10] Carnat A, Carnat AP, Chavignon O, Heitz A, Wylde R, Lamaison JL. Luteolin 7-diglucuronide, the major flavonoid compound from Aloysia triphylla and Verbena officinalis. Planta Med.1995; 61(5): 490.

[11] Calvo MI, San Julian A, Fernández M. Identification of the major compounds in extracts of Verbena officinalis L. (Verbenaceae) by HPLC post-column derivatization. Chromatographia. 1997; 46(5-6): 241- 4.

[12] El-Hela AA, Al-Amier HA, Ibrahim TA. Comparative study of the flavonoids of some Verbena species cultivated in Egypt by using high - performance liquid chromatography coupled with ultraviolet spectroscopy and atmospheric pressure chemical ionization mass spectrometry. J. chromatogr. A. 2010; 1217: 6388-93.

[13] El-Hela AA, Luczkiewcz M, Cisowski W. Phenolic acids of Verbena bipinnatifida (Nutt). Qualitative and quantitative analysis of free and hydrolysis-liberated phenolic acids. Acta Pol Pharm._Drug Research. 1999; 56(1): 73-7.

[14] Ono M, Oishi K, Abe H, Masuoka C, Okawa M, Ikeda T, Nohara T. New iridoid glucosides from the aerial parts of Verbena brasiliensis. Chem. Pharm. Bull. 2006; 54(10): 1421- 4.

[15] Castro-Gamboa I, Castro O. Iridoids from the aerial parts of Verbena littoralis (Verbenaceae). Phytochemistry. 2004; 65(16): 2369- 72.

[16] Li Y, Ishibashi M, Satake M, Oshima Y, Ohizumi Y. A new iridoid glycoside with nerve growth factor-potentiating activity, gelsemiol 6'-trans-caffeoyl-1-glucoside, from Verbena littoralis. Chem. Pharm. Bull. 2003; 51(9): 11035.

[17] El-Hela AA, Sowinski P, Krauze-Baranowska M. Iridoids and phenylethanoids of Verbena bipinnatifida nutt. Acta Pol Pharm.-Drug Research. 2000; 57(1): 65-8.

[18] Lahloub FM, Salama OM, Mansour ES. Phenylpropanoid and iridoid glycosides from Verbena officinalis. Bull. Fac. Pharm. Cairo Univ. 1990; 28: 75.

[19] El-Domiaty M, El-Shafai AM, Abdel-Aal M. Iridoids and phenylpropanoid glycosides of Verbena tenera. Alex. J. Pharm. Sci. 1999; 13: 1.

[20] Rocha GF, Calloni S, Rodriguez Morcelle MI, Apóstolo NM, Rosso AM, Parisi MG. In vitro evaluation of the antimicrobial and the antioxidant activities of extracts and essential oils of Verbena bonariensis. May 2013 Conference: Bioveg. 2013.

[21] Shi C, Song K, Zhang X, Sun Y, Sui Y, Chen Y, Jia Z, Sun H, Sun Z, Xia X. Antimicrobial activity and possible mechanism of action of citral against Cronobacter sakazakii. PLoS ONE. 2016; 11(7): e0159006.

[22] Ardakani MS, Mosadeggh M, Shafaati A. Volatile constituents from the aerial parts of Verbena officinalis L. (Vervain). Iran J Pharm Res. 2003; 2: 39-42.

[23] Chalchat JC, Garry RP. Chemical composition of the leaf oil of Verbena officinalis L. J. Essent. Oil Res. 1996; 8: 41920 . 
[24] De Martino L, D’Arena G, Minervini MM, Deaglio S, Sinisi NP, Cascavilla N, De Feo V. Active caspase-3 detection to evaluate apoptosis induced by Verbena officinalis essential oil and citral in chronic lymphocytic leukaemia cells. Rev Bras Farmacogn. 2011; 21(5): 869-73.

[25] Royal Botanic Gardens, Kew. WCSP "World Checklist of Selected Plant Families Published on the Internet. 2021.

[26] RHS A-Z encyclopedia of garden plants. United Kingdom: Dorling Kindersley. 2008; 1136.

[27] European pharmacopoeia. 5 ed. Strasbourg: Council of Europe: E.P.C. 2004; 217-218.

[28] Bașer KHC, Demirci B, Tabanca N, Özek T, Gören N. Composition of the essential oils of Tanacetum armenum (DC.) Schultz Bip., T. balsamita L., T. chiliophyllum (Fisch. \& Mey.) Schultz Bip. var. chiliophyllum and T. haradjani (Rech. fil.) Grierson and the enantiomeric distribution of camphor and carvone. Flavour Fragr J. 2001; 16: 195200.

[29] Gürbüz İ, Demirci B, Franz G, Başer KHC, Yeşilada E, Demirci F. Comparison of the volatiles of Daphne pontica L. and D. oleoides Schreber subsp. oleoides isolated by hydro-and microdistillation methods. Turk. J. of Biol. 2013; 37(1): 1-8.

[30] Babushok VI, Linstrom PJ, Zenkevich IG. Retention indices for frequently reported compounds of plant essential oils. J. Phys. Chem. Ref. Data. 2011; 40(4): 1-7.

[31] Sourki AH, Ghani A, Kiani F, Alipour A. Phytochemical profiles of lemon verbena (Lippia citriodora H.B.K.) and its potential application to cookie enrichment. Food Sci. Nutr. 2021; 9(6): 3100-13.

[32] Beigi M, Torki-Harchegani M, Pirbalouti AG. Quantity and chemical composition of essential oil of peppermint (Mentha piperita L.) leaves under different drying methods. Int. J. Food Prop. 2018; 21(1): 267-76.

[33] Ibrahim TA. Chemical composition and antimicrobial activity of essential oil of Salvia bicolor Desf. growing in Egypt. J. Essent. Oil-Bear. Plants. 2014; 17(1): 104-11.

[34] Ibrahim TA, El-Hela AA, El-Hefnawy HM, Al-Taweel AM, Perveen S. Chemical composition and antimicrobial activities of essential oils of some coniferous plants cultivated in Egypt. Iran. J. Pharm. Sci. 2017; 16(1): 328-37.

[35] CLSI. Performance Standards for Antimicrobial Susceptibility Testing, 29th ed.; CLSI Supplement M100. Wayne: CLSI. 2019.

[36] Wiegand I, Hilpert K, Hancock REW. Agar and broth dilution methods to determine the minimal inhibitory concentration (MIC) of antimicrobial substances. Nat. Protoc. 2008; 3: 163-75.

[37] Bakkali FS, Averbeck D, Idaomar M. Biological effects of essential oils- a review. Food Chem. Toxicol. 2008; 46: 446-75.

[38] Guimarães AC, Meireles LM, Lemos MF, Guimarães MCC, Endringer DC, Fronza M, Scherer R. Antibacterial activity of terpenes and terpenoids present in essential oils. Molecules. 2019; 24: 2471.

[39] Guo F, Chen Q, Liang Q, Zhang M, Chen W, Chen H, Yun Y, Zhong Q, Chen W. Antimicrobial activity and proposed action mechanism of linalool against Pseudomonas fluorescens. Front. Microbiol. 2021; 12: 562094.

[40] Dorman HJ, Deans SG. Antimicrobial agents from plants: Antibacterial activity of plant volatile oils. J. Appl. Microbiol. 2000; 88: 308-16.

[41] Vilela GR, De Almeida GSt, D’Arce MA, Moraes MH, Brito JO, Silva MF, Silva SC, Piedade SM, Calori-Domingues MA, da Gloria EM. Activity of essential oil and its major compound, 1,8-cineole, from Eucalyptus globules Labill., against the storage fungi Aspergillus flavus Link and Aspergillus parasiticus Speare. J. Stored Prod. Res. 2009; 45(2): 108-11.

[42] Leite AM, Lima ED, de Souza EL, Diniz MD, Trajano VN, de Medeiros IA. Inhibitory effect of $\alpha$-pinene, $\beta$-pinene and eugenol on the growth of potential infectious endocarditis causing Gram-positive bacteria. Braz. J. Pharm. Sci. 2007; 43(1): 121-6. 